\title{
Bireyve
}

Toplum

\section{Kurgu ile Gerçeklik Arasında Gezi Parkı Eylemleri ve Soysal Medya}

\author{
Yrd.Doç.Dr Hasan TOPBAŞ ${ }^{1}$ \\ Yrd.Doç.Dr Umur IŞIK ${ }^{2}$
}

Öz: Gezi parkı eylemleri farklı politik muhayyileleri ateşleyen ve farklı sosyal bilimlerini yeni araştırma gündemlerine yönelten yapısıyla yakın dönem Türkiye tarihinin önemli toplumsal olgulardan birisidir. Özellikle iletişim bilimciler açısından "Gezi parkı" eylemleri genelde kitle iletişim araçları, özelde sosyal medya toplumsal ve siyasal alanda nasıl bir etki yarattığı ve kitleleri nasıl harekete geçirdiği noktasında üzerinde durulması gereken bir sosyal hareketlilik olarak karşımıza çıkmaktadır. Gezi parkı eylemleri olarak medyada karşılık bulan Taksim Meydanını Yayalaştırma Projesi’ne tepki olarak ortaya çıkan ve kısa sürede sosyal medyanın etki gücüyle ülkeye ve dünyaya yayılarak hükümet karşıtlllığına dönüşen toplumsal bir hareket niteliği kazanmıştır. "Gezi Parkı” eylemleri üzerinden farklı siyasal görüşlere mensup bireylerin, gezi eylemlerini kendi ideolojik bakış açılarıyla ele alarak, bazı grup ve bireylerin olayı kullanarak kişisel popülarite ve rant elde etmeye çalışması ve sosyal medya üzerinden yoğun paylaşımlarda bulunması, protestoların çıkış amacını gölgeleyerek amacından sapmasına neden olmuştur. Özellikle eylemlerin hükümet yanlısı ve hükümet karşıtı grupların çatışması haline dönüşmesine, kitlelerin sokaklara dökülmesine, şiddet olaylarının yaşanmasına ve ülkenin bu olaylar sonucunda ciddi sıkıntılar

1 İnönü Üniversitesi, İletişim Fakültesi, Halkla İlişkiler ve Tanıtım Bölümü, hasan. topbas@inonu.edu.tr

2 Gazi Üniversitesi İletişim Fakültesi Gazetecilik Bölümü 
yaşamasına yol açmıştır. İnternet üzerinden yapılan yoğun paylaşımlar ve her iki taraftan farklı grupların olaylara provakatif yaklaşımı, protesto eylemlerinin sivil bir direniş ve halk hareketi olma iddiasını gölgelediği gibi gerginliğin artmasına ve hatta ölümlerin yaşanmasına sebebiyet vermiştir.

Anahtar kelimeler: Siyaset, sosyal, iletişim, sosyal medya.

\section{Giriş}

Toplumsal bir "kip" olarak iletişim kavramını incelemek için kabaca medya ekolojisi olarak adlandırabileceğimiz, ana akım (mainstream) ve eleştirel iletişim alanları içinde fazla rağbet görmeyen bir alan üzerinde çalışmayı gerektirmektedir. Medya ekolojisi yaklaşımı, iletişim süreçleri içinde mesaj içeriğini ya da iletişimin ekonomi-politiğini değil, iletişim teknolojisinin kendisini (söz, yazı, baskı, televizyon, internet, vs.) ilgi alanına almakta ve araştırma nesnesi olarak incelemektedir (Nalçaoğlu, 2011: 163-165).

N. Postman "What is Media Ecology?" adlı eserinde medya ekolojisini, iletişim medyasının insan algısını, anlayışını, duygulanımını ve değerlerini nasıl etkilediği üzerinde durmakta ve ekoloji veya çevrenin (environment) insanlara belli düşünme, hissetme ve davranma biçimlerini empoze eden karmaşı mesaj sistemlerinden oluştuğunu ifade etmektedir (Postman, 2009). O halde çoklu iletişim teknolojilerin etkileşimi ile şekillenen ancak bunlar içinde bir tanesinin baskın rol oynayabileceği verili bir medya ekolojisi bireylerin algıladıklarını, söylemlerini ve davranışlarını yapılandırmakta, insanlara belli roller yüklemekte ve bu rollerin yerine getirilmesini sağlamaktadır. Aynı șekilde yapılması ve/ veya yapılmaması gereken şeyleri ortamın doğasına göre farklı şiddet ve formellikteki yaptırımlarla denetlemektedir (Nalçaoğlu,2011: 163-165).

Toplumsal iletişim kipi, verili bir zaman-mekân kesitinde bir topluluğun ya da bütün bir toplumun kendisini hangi iletişim teknolojisi ile başat olarak özdeşleştirip kurduğunu, inşa ettiğini anlatan bir kavram olarak karşımıza çıkmaktadır. Bu iletişimin toplumsal kipi, basit 
bir biçimde insanların kafalarında zaten var olan fikirleri aktarmak için şu veya bu medyayı seçmelerini değil, belli bir zaman mekân kesitinde kendilerine iradeleri dışında sunulmuş olan mecralardan birine yönelmiş olmalarından ötürü, belli şeyleri düşünmelerini, bunlara uygun değer sistemleri geliştirmelerini ve yine bunlara uygun davranışlar sergilemelerini anlatmaktadır (Nalçaoğlu, 2011:165).

İletişimin toplumsalın kurulusunda başat rol oynadığını, gerçekte "toplumsal" dediğimiz zaman aklımıza bir örüntü, bir ağ, bir ilişkiler bütünü gelmesi gerektiğini de düşünecek olursak siyasal alanda, -önemli ölçüde- bu örüntü, ağ ve ilişkiler bütünü içerisinde medya aracıllğıyla kurulmakta, üretilmekte ve sunulmaktadır. Dolayısıyla medya, günümüzde bireyin etkin olarak siyasal sisteme ilişkin inanç, değer ve bilgilerin öğrenilmesinde, benimsemesinde rol oynamakta, siyasal-ideolojik kimliğinin biçimlenmesinde, böylelikle akılcı, duygusal ya da ideolojik bağlılığa dayalı siyasal tutum ve davranışlar sergilemesinde son derece etkili rol oynamaktadır.

Tarihin her döneminde olduğu gibi, modern dönemde de siyaset mekanizması kendi var oluşunu ve meşruiyetini inşa edecek araçları ve ortamları oluşturmaktadır. Siyasetin varlık sahasında görünmesinin araçları, kimi zaman ekonomik, sosyal, kültürel sermaye, kimi zaman ve çoğunlukla da dönemin iletişim araçları (toplumsal iletişim kipi) olduğu bilinen bir gerçektir. Zamanın ruhuna ve hâkim algısına uygun siyaset biçimi ve iletişim araçlarının (toplumsal iletişim kipi) formları değişse de, siyasetin görme/ görünme zorunluluğu bütün tarih boyunca devam etmektedir (Topbaş, Babacan 2013: 143-178).

İnternetin siyasal iletişim sürecinde öneminin artması ve buna bağlı olarak da yoğun olarak kullanılmaya başlaması, bu sürecin önemli parçalarından olan siyasal aktörlerin de interneti siyasal amaçlı kullanımını gündeme getirmiştir.

İnternetin siyasal içerikli kullanımı ile siyasal tutumlar arasındaki ilişki, siyasal yeterlilik, siyasal ilgi ve siyasal katılım kavramları özelinde oldukça ilgi çekici ve yeni bir konudur. Zira internetin diğer geleneksel kitle iletişim araçları ile kıyaslandığında gündelik yaşamda ve 
özellikle siyasal bilgi edinmeye yönelik kullanımı 1990'ların sonlarından itibaren yaygınlaşan bir karakter arz etmesi siyasal tutumlar üzerindeki olası etkisinin ele alınmasını zorunlu hale getirmektedir. Bireyin siyasal sisteme katılımının temel amaç olduğu katılımcı demokrasilerde toplumsal iletişim kipi bağlamında internet (sosyal medya) siyasal yeterlilik hissine sahip vatandaşların siyasal olarak daha aktif ve katılımcı bireyler haline gelmesine katkı sağlamaktadır. Bu noktada bireyler siyasal sisteme ilişkin daha fazla ilgi ve bilgi sahibi olmakta ve siyasal sistemin şekillenmesi noktasında daha fazla tatmin yaşamaktadırlar. Artık günümüzde internet/sosyal medya günlük yaşamın her alanında kullanıldığg gibi siyasal aktörlerin bireyselleşmesinde, bireysellikten toplumsallığa dönüşmesinde ve siyasal davranışların şekillenmesinde önemli bir bileşen olarak karşımıza çıkmakta ve siyasal katılım sürecinin vazgeçilmez bir toplumsal iletişim kipi haline gelmektedir (Timisi, 2003: 41-42).

İnternetin kullanım alanının yaygınlaşması sadece seçim dönemlerinde sandık başına giden bireylerin oy kullanma davranışıyla sınırlı kalmamakta, aksine yaşanan sosyal ve siyasal değişimlere doğrudan dahil olmalarına olanak tanımaktadır. Bu bağlamda, internetin diğer kitle iletişim araçlarından farkı ortaya çıkmakta ve etki alanının genişliğinin yanı sıra, bireylerin anında iletişim kurması ve geribildirim olanağının sağlanması onu diğer kitle iletişim ortamlarından ayıran en önemli fark olarak karşımıza çıkmaktadır.

Özellikle son dönemlerde dünyanın farklı coğrafyalarında yaşanan birçok olayda (Arap Baharı) meydana gelen krizler ve halkın bu yaşananlara karşı tepkisini göstermesinde özellikle sosyal medya (facebook-twitter) üzerinden yürütülen faaliyetler ve kitlelerin ayaklanması, olaylara müdahil olması, sosyal medyanın siyasal arenada etkisinin ortaya konulması açısından önemlidir.

Türkiye'de de son dönemlerde yaşanan "Gezi Olayları" da sosyal medyanın siyasal alanda nasıl bir etki yarattığı ve kitleleri nasıl harekete geçirdiği üzerinde araştırması yapılması noktasında önemli bir örnek oluşturmaktadır. Gezi olayları olarak medyada karşılık bulan ve uzun bir süre gündemi işgal eden olayların çıkış noktası İstanbul Taksim 
Meydanı Yayalaştırma Projesi' dir. Taksim Meydanı Yayalaştırma Projesine tepki olarak ortaya çıkan ve kısa sürede sosyal medya aracıllğıyla tüm ülkeye ve dünyaya yayılarak hükümet karşıtı bir sokak hareketine dönüşen Gezi Parkı eylemleri, son yılların en önemli toplumsal-siyasal gelişmelerinden biri olarak değerlendirilmektedir (Ete, Taştan, 2013: 85).

Gezi eylemlerinin siyasal tarihimizde önemli bir momente denk geldiğine kuşku yoktur. Eylemlerin motivasyonu, hedefi ve sonuçları daha uzun süre siyasal-sosyal hayatımızı etkilemeye devam edecek ve gelişmeler bu olaya atıfta bulunularak sosyal ve siyasal bilimciler tarafından analiz edilmeye çalışılacaktır. Çalışmamız olayların ortaya çıkışına, sonlanışına ve kısa vadedeki sonuçlarına dair yakından ve nesnel gözlemler yapmaktan daha ziyade (gösterilerin ilk günkü bileşenlerinin en meşru kısmını mercek altında tutup zaman içerisinde eylemci profilindeki yaşanan değişimi) sosyal medya aracılığıyla eylemlere yüklenen anlamı eylemin gelişim sürecini gözden geçirmeyi ve soysal medyanın konumunu analiz etmeyi amaçlamaktadır. Yaşadığımız toplumda sosyal medya kullanıcı sayısının her geçen gün artması ve gerek dünyanın çeşitli bölgelerinde ve gerekse ülkemizde görülen toplumsal olayların eylem ve iletişim ortamının oluşturulmasında sosyal medyanın öneminin ve etkinliğinin analiz edilmesini gerekli kılan en önemli bir olgu olmasını sağlamaktadır.

Bu çalışmada, sosyal medyanın insanları etkileme gücü göz önünde bulundurularak kurgu ile gerçeklik arasında Gezi Parkı eylemleri ile ilgili sosyal medyada yer alan mesajların (gazeteciler-sanatçılar, siyasetçiler) farklı söylemlerin inşa edilişini anlamayı ve söylemlerin analizi ile çözümlemesi ile gerçek ile kurgu arasındaki farklılığı ortaya koymayı hedeflenmektedir.

Üretilen yeni dilsel kodlar ve çoğalan kanallar nedeniyle "bilgi” (nesnel olan) üretilen, kurgulanan ve tüketilen bir meta haline dönüşmüştür. Siyasal bilginin üretilmesi toplumsal iletişim kip’inden bireylere aktarılması, bireyleri bilgi bombardımanı altına alarak binlerce bilgi arasından en doğruyu seçmek neredeyse imkansız olan sanal bir alemin içinde kaybolmayı, yalnızlaşmayı, yabancılaşmayı ve savunmasızlı̆̆ 
beraberinde getirmektedir. Çünkü sosyal medya da bilgi bir yandan üretim sürecinden geçerken nesnel gerçeklilikten koparılmakta kurgusallaşmakta hipergerçeklik (aşkın gerçeklik) haline getirilmektedir. Tüketim metası haline getirilen bilgi, medyanın ideolojisi ve bilgiyi üreten kurum ve kişilerin ideolojileri ile özdeş hale gelmektedir.

\section{Dijital Çağ, Dijital Siyaset: Siyasal Bilginin Üretimi}

İletişim alanındaki değişimler sosyal ilişkileri ve dolayısıyla da toplumsal yapıyı derinden etkilemektedir. Aynı şekilde toplumsal yapının ortaya koyduğu ihtiyaçlar da teknolojik gelişmeleri tetiklemekte sosyal medyanın sosyolojik-siyasal boyutu incelenirken toplumsal, tarihsel değişimlerle teknolojik gelişmelerin etkileşimli olarak incelenmesini gerektirmektedir.

Sosyal paylaşım ağlarının kendi üreticilerini, tüketicileri arasından oluşturabilmesine olanak sağlayan İnternet teknolojisinin temelinde Web 2.0 tabanlı, etkileşimli uygulamadır. 2004 yılında bir konferansta O'Reilly ve MediaLive International arasında gerçekleşen bir beyin fırtınası sonucu ortaya çıkan Web 2.0 kavramı, zamanla yaygın olarak kullanılan bir kavram haline gelmiştir (O’Reilly, 2007: 17). Web 2.0 teknolojileri bloglar, wikiler, sosyal ağ merkezleri(facebook, myspace gibi), web tabanlı iletişim biçimleri (chat-chat grupları), fotograf paylaşımı (flickr), video ekleme ve paylaşma (youtube gibi)sosyal açıklamalar, web sitelerinin yer imleri ve daha fazlasını kapsamakta (Balc1, Tarhan ve Bal, 2013:108) ve toplumsal iletişim kipi olarak karşımıza çıkmaktadır.

Politik ve kültürel yaşam da bu ağ yapısına göre yeniden yapılanmaktadır. Manuel Castells, bilgi ve iletişim teknolojilerinin gelişmesiyle küresel anlamda ortaya çıan böyle bir dönüşümün ağ toplumunu oluşturduğunu savunmaktadır (Castells, 2011)

$\mathrm{Bu}$ ağ toplumunda, bilgisayar ve internet teknolojilerinde görülen gelişmelerin mesaj iletiminde zamanı kısaltıp mekânları birbirine yakınlaştırmasıyla 'ileti yönetimi' her zamankinden daha önemli hale gelmektedir. Özellikle WEB 3.0 teknolojisiyle birlikte iletişimin etkileşimli 
bir yapıya dönüşmesi ve web ortamında oluşturulan sosyal medya alanlarıyla birlikte iletişim küresel bir boyut kazanmaktadır. Sosyal medya ortamındaki iletişim, kişiler arası iletişim boyutundan çıkarak ekonomik ilişkileri, siyaseti, diplomasiyi etkileyen bir boyuta ulaşmakta, dijital hayatın her alanı sarmaladığı dünyada siyasetin üretilme ve tüketilme biçimlerinde de köklü değişimler yaşanmaktadır.

Teknolojik değişimlerle dönüşüme uğrayan siyasal ve kültürel yaşam, yeni dönemde dönüşümün iletişimsel boyutu yeniden tanımlanmaktadır. Teknolojik gelişmeler günümüzde siyasal alana da nüfuz etmekte, bireylerin siyasete katılımlarını geleneksel yolların dışına çıkararak, pasif seçmen kitleleri aktif kitlere dönüştürmektedir. Bilgi ve iletişim teknolojilerinin dijital siyasette yarattığı en etkili örnek Türkiye'de 'Gezi Parkı Olayları' olmuştur. Bu dönemde gençler dijital siyasette aktif rol oynamakta ve genç kuşak odalarında yaşamakta ve sosyalleşmelerini odalarından çıkmadan dijital araçlarla sürdürebilmektedir. Bu noktada siyasal aktörlerin sadece basın açıklaması yapmaları gençleri siyasete çekmede nasıl yetersiz kalıyorsa, sadece sosyal medya ağları üzerine odaklanmak da dijital siyasal süreçte yetersiz kalacaktır (Ünüver, 2013).

$\mathrm{Bu}$ noktadan bakıldığında, sosyal medyanın faydaları;

Organize olmayı kolaylaştırması,

- Gerçekleri kolaylıkla öğrenebilme imkânı sağlaması,

- Bireyler arasında iletişimi arttırması,

- Fikirlerin hızlıca yayılması,

- Organizasyon ve iletişim maliyetini düşürmesi

- Daha çok sayıda insanın siyasi veya sosyal olaylara daha kısa sürede reaksiyon gösterebilmesi (Ersöz,2005, 122-129) şeklinde açıklanabilir. Burada vurgulanması gereken önemli bir nokta ise, sosyal ağlar halk hareketlerini tetikleyen araçlar değil, organize olma ve hareketi başlatma maliyetini düşürerek ve hızını arttırarak kolaylaştıran araçlardır. (Çildan, Ertemiz vd. 2012) 
Teknolojinin tüm toplumsal alanları kapsayan ve dönüştüren bu determinist etkisi ile "teknolojiyi kim kontrol etmekte ve teknoloji kime hizmet etmektedir?” soruları önemli bir tartışmayı da beraberinde getirmektedir. Lyotard'ın postmoderniteyi tanımlarken kullandığı betimlemeden yola çıkacak olursak, endüstri toplumu sonrası ortaya çıkan teknoloji bazlı toplumsal değişimlerin en önemli nedeni, toplumsal değişimlerin bilginin konumu üzerine yaptığ 1 vurgulardır. Lyotard'a göre 1950 sonrası teknoloji, dilbilim ve iletişim alanına etki etmeye başlamış ve teknolojik dönüşümler, herhangi bir olgunun araştırılması ve bu araştırma sonucu elde edilen bilginin aktarımı konusunda önemli dönüşümleri meydana getirmiştir (Balibar, 1991). İletişim kuramından yola çıkacak olursak bilgiyi üreten ile bilgiyi alan arasındaki kanallar çeşitlenmiş ve değişime uğramıştır. Bunun yanı sıra özellikle bilgisayar teknolojisindeki gelişmeler farklı dilsel alanların oluşumuna yol açmış ve üretilen yeni dilsel kodlar, çoğalan kanallar nedeniyle bilgi üretilen ve tüketilen bir meta haline dönüştürmüştür (Lyotard, 2000).

Bilginin üretilmesi ve bir mecradan akıtılarak nihai tüketicinin kullanımına sunulması, nihai tüketiciyi büyük bir bombardıman altına alarak, binlerce bilgi arasından en doğruyu seçmek gibi neredeyse imkansız bir alanın içinde kaybolmaya, yalnızlaşmaya ve savunmasızlığa iterken, bir yandan da bilgi üretim sürecinde gerçekten koparılarak kurgusallaşan ya da Baudrillard'ın deyimi ile hipergerçeklik (aşkın gerçeklik) haline gelen ve tüketim metası haline getirilen bilgiyi üreten kurumların ideolojilerinin hedefi haline gelmektedir (Baudrillard, 2005).

$\mathrm{Bu}$ noktadan yola çıkarak, bilgi üretim sürecini ve kanallarını üreten ve elinde tutan siyasal aktörlerin, teknolojiyi ideolojik bir aygit olarak kullanması karşısında, savunmasız kalan bireylerin, yine teknolojiyi kullanarak bir direniş alanı olarak dijital alanı kullanabilmesinin olanaklarını sağlamaktadır. Bununla birlikte Frankfurt Okulu düşünürlerinin işaret ettiği gibi medyanın tüm toplumsal alanı belirleme ve bilgi üretme kanallarının ideolojik bir süzgeçten geçirilerek bireye sunulması, bireyi gerçeğe ulaşma yolunda sonuçsuz bir maceraya sürüklemektedir. Medyanın ideolojisi bir anlamda ürettiği bilginin hizmet ettiği çıkar gruplarının ideolojisi ile özdeşleşmektedir (Kaplan, Ertürk, 2012: 7-11). Medyanın yoğun propagandasına maruz birakılan bireyler 
ise Baudrillard'ın ortaya koyduğu üzere, kurgulanan gerçek artık gerçeğin yerini almış ve kitleler kurgulanmış bir gerçeğin içinde yaşayan sessiz yığınlar haline gelmiştir (Baudrillard, 2005).

Dijitalleşme bir yandan bilginin hızlı üretimi, yayılımı ve tüketiminin önünü açarken, bir önemli gelişmeyi de beraberinde getirmiştir: Teknolojinin ucuzlaması ve yaygınlaşması. Ayrıca, 15. yüzyılda matbaanın bulunması ile birlikte ortaya çıkan bilginin halka ulaşması ve halkın bilgiyi kullanmasına benzer bir süreci 21. yüzyılda sosyal medya ile yaşanmakta, yeni bir aydınlanma çağını doğurabilir mi? sorusunu da beraberinde getirmektedir. 20. Yüzyılın sonlarından başlayarak devam eden teknolojinin yaygınlaşması süreci, bireylerin bilgisayar sayesinde her türlü bilgiye ulaşmasını kolaylaştırırken, bir yandan da dijital aletler sayesinde görsel sanatlar ve özellikle fotoğraf ve görüntü teknolojileri de sokağa inerek. (Dilmen, 2007: 214) yaygınlık kazanmaktadır.

Bireyin daha önce sadece izleyicisi olduğu filmler, sinemalar ve diğer görüntüler, artık dijital teknolojilerin sokağa inmesi ile bireyin yapımc1sı ve yöneticisi olduğu bir kurgusal görsellik alanı oluşturma imkanını bireye sağlamaktadır. (Vural, Bat, 2010: 6) Oluşturulan bu görsellik ise internet üzerinden tüm dünyaya sunulmaktadır. Özellikle sosyal paylaşım siteleri olarak adlandırılan popüler sanal ortamlar sayesinde bireysel üretimler birkaç saat içinde binlerce kişiye ulaşmaktadır.

Gittikçe yaygınlaşan sosyal ağlara son beş yılda, sosyal ağ sitelerine, on milyonlarca internet kullanıcısı talep göstermiş ve sosyal ağlar hem yetişkin hem de genç kullanıcılarla değerini arttırmıştır. Bu noktada sosyal ağlarla ilgili sayısal verilere bakıldığında şaşırtıcı ve ilginç rakamlarla karşılaşılmaktadır.

- Üniversite öğrencilerinin \% 82'si ve 19 yaş altının \%55’i sosyal ăg kullandığı,

- 13-19 yaş arasının \%28'inin blogu bulunduğu,

- İnternet kullanıcılarının ya \%28'i etiketlenmiştir ya da fotoğraflar, yeni hikayeler, ya da blog mektupları gibi online içeriklerine göre siniflandirilmakta, 
- İnternet kullanıcılarının \%48'i YouTube gibi video paylaşım sitesi kullandığı (Vural, Bat, 2010: 10) sonuçlarından yola çıkarak sosyal medyanın kullanım taleplerinin büyük oranda arttığını ve bu artışın da toplumsal-siyasal alanda üretilen ve tüketilen bilgi yayma gücünü net bir şekilde ortaya koymaktadır. Örneğin artık sanat galerilerinin, sinema salonlarının yerini sosyal paylaşım siteleri almıştır. Facebook üzerinden günlük paylaşılan amatör videoların sayısının 500.000'in üzerinde olduğu bilinmektedir. Youtube, flicker vb. gibi popüler video ve fotoğraf paylaşım siteleri sayesinde bu ürünler gün içinde binlerce kişiye ulaşabilmektedir. Bireylerin yönettiği amatör bloglar, web siteleri, haber portalları geometrik bir biçimde artmaktadır.

Bugün dünyanın her yerinde elinde bir kamera ile görüntüler çeken, onları kurgulayarak kendi bakış açılarını ortaya koyan insanların ürünlerini sundukları sanal ortamlar aynı zamanda düşüncelerin, bilgilerin paylaşıldığı ortamlar olmaya başlamıştır. Sanal ortamlar üzerinden bireyler sosyal topluluklar kurabilmekte, örgütlenebilmekte ve harekete geçebilmektedir. (Binark, 2007: 6) Yakın zamanda "Arap Baharı" olarak adlandırılan ve Tunus'ta, Fas'ta, Mısır'da ve Libya'da rejim değişikliğine yol açan halk ayaklanmalarının örgütlenme yeri olarak sanal ortamlar gösterilmiştir. Yine yakın tarihte Türkiye'de ortaya çıkan YÖK protestolarına katılan liseli öğrenciler sanal ortamlarda bir araya gelen ve birbirlerini ilk defa gören bireylerden oluşmuş olmalarına karşın binlerce liseli sokaklarda yürüyerek protesto gösterileri yapabilmiştir.

Dünyayı sarsan Wikileaks belgeleri yine sanal ortamdan dağıtılarak ve yayılarak milyonlarca insana ulaşmıştır. Amerikan ordusunu Irak'ta çok zor durumda bırakan fotoğraf kareleri bireylerin cep kameraları ile çektiği görüntülerin servis edilmesi ile ortaya çıkmıştır. Yine Türkiye'de 22 Temmuz 2007 seçim döneminde Adana'da Abdurahman Boztaş isimli vatandaşın "Biz fırıldak değiliz" adlı video klibi youtube üzerinden izlenme rekorları kırmıştır. Aynı dönem ve sonraki seçim dönemlerinde bağımsız adayların sosyal paylaşım siteleri üzerinden yürüttüğü seçim kampanyaları büyük ses getirmiştir (Binark, 2007: 11).

Günümüzde artık sosyal medya aracılığıyla Facebook, Twitter, Instagram, Thumbler, Foursquare, Vine ve benzeri uygulamalar üzerinden 
iletişim kuran bireyler duygu, düşünce ve toplumsal alanda yaşanan olaylara karşı sergiledikleri tutumlarını görsel-işitsel-yazılı paylaşmakta, (-ki bunlar fotoğraf, video, yazılı mesaj-) bu paylaşımlar zaman zaman kitleleri yönlendirecek şekillerde kamusal alanda karşılığını bulmaktadır. İnternet aracılığıyla siyasal içerikli paylaşımların yapılması, geniş kitlelerin bu olaylara dahil olmasını sağlamakta dolayısıyla kitlelerin yaşanan olaylara direk dahil olması sonucunu beraberinde getirmektedir

Kisaca günümüzde teknoloji ekonomiden siyasete, kültürden sosyal ilişkilere kadar her şeyi etkisi altına almakla kalmayıp yeni algı kalıplarının oluşmasını da sağlamaktadır. Zaman, mekan ve ilişkiler anlamında çok şeyi değiştiren teknoloji ve uzantıları düşünme ve eylem biçimlerimizi, gündelik hayattan, kültürel ve siyasal hayatımıza kadar tüm alg1 dünyamızı etkileyen önemli bir etken konumuna geldiği görülmektedir (Yeniçıtıtı, 2014: 263-284).

\section{Medya Söylemleri Bağlamında Eylem ve Eylemcilerin Tanımlanması}

Gezi Parkı eylemlerine bir sivil demokrasi hamlesi olarak sahip ç1kan ve/ya hareketin Başbakan Erdoğan başta olmak üzere Ak Parti hükümeti, hükümet politikaları ile bu siyasi aktörlerin temsil ettiği değerler bütününe karşı eleştirel yaklaşımını kendisine yakın bulan yorumcular, sokak muhalefetine katılan eylemcilere dair bazı olumlu varsayımlar ürettiği görülmektedir. Bu muhayyel ortalama eylemci profili, kamuoyunda yaşanan tartışmalarda sorgulanmaksızın dolaşıma sokulmuş ve toplumun belirli bir kesiminin gösterilere dair algısını büyük ölçüde şekillendirilmiştir. Yukarıda da bahsedildiği üzere bu yaklaşım, gezi parkı eylemlerine katılan kitlelerin toplumun geneli nezdinde popülaritesini ve albenisini artıracak bir "anjelizm" kampanyasını beraberinde getirmiştir (Hatem Ete Coşkun Taştan, 2013-86). Bu temel pozisyon, okumaları 'Gezi Parkı Gençliğì şeklinde kavramsallaştırılan bir grup insanın başka bir evrenden gelmiş olabileceği sonucuna ulaştıracak bazı yorumlara kaynaklık etmektedir. Örneğin Ertuğrul Özkök, 3 Haziran 2013 tarihinde Hürriyet' gazetesindeki, “Kimdir Bu İnsanlar?” konulu yazısında, eylemlere katılan insanları "sınflar üstü, nesiller üstü, cinsiyetler 
üstü, kibirler üstü, duygular üstü, partiler üstü, tavirlar üstü ve takımlar üstü” bir kolektif varlık olarak yorumlamaktadır. Yine aynı çerçevede, Can Dündar, 8 Haziran 2013 tarihinde Milliyet'teki, "Taksim: Özlediğimiz Türkiye’nin Maketi, konulu yazısında, "bir önceki gece sabaha kadar içen 'ayyaşlar' Kandil gecesi müminlere simitle çay dağıtıyordu. Bir köşede Apo resimleri önünde 'gerilla' halayı çekilirken öbür köşede Mirzabeyoğlu için gösteri yapılıyordu. Zıt kutuplar bir aradayken, ortada otorite ve kolluk yokken, o büyük şenlikte tek bir kavga, sataşma, taciz yaşanmiyor, herkes neşe içinde birbirine yiyecek, ilaç, kitap taşıyordu" diyerek polisin orantısız güç kullanımının olayları tetikleyici etkisini ön plana çıkartarak, gezi parkı eylemlerini ve eylemcilerini, tüm kötü sıfat ve özelliklerden arınmış -dolayısıyla kimsenin daha önce görmediğigrup asabiyetini saf dışı bırakan bir grup insanın spontane şekilde sokaklara çıkıp eylemlere katılması yeni bir durumun ortaya çıkması olarak yorumlamıştır. Böylece eylemler, bünyesinde bulundurduğu siyasi parti, dernek, sivil toplum kuruluşları ve bireysel katılımcıların tüm siyasi mirasını bir kalemde silen bir işlev gördügüünü ve eylemcileri ve eylemleri tüm siyasi ve tarihsel bağlamlardan soyutlayarak adeta laboratuar ortamında kamuoyuna sergilemek için bir araya gelen insanlar ve ülkenin tüm sorunlarını çözebilecek bir yapıda (Ete, Taştan, 2013; 89) olduklarına göndermede bulunduğu görülebilmektedir.

Ahmet İnsel'in Radikal Gazetesi'nde 16 Temmuz 2013 tarihli , 'Her yer taksim, her yer demokrasi', yazısında gezi eylemleri'nin ana enerjisini oluşturan tepki ve ona eşlik eden talepler, vatandaşların kendi yaşam alanlarını ilgilendiren konularda görüşlerinin, tercihlerinin dikkate alınmaması, onlara sadece seçimden seçime fikirlerine değer verilirmiş gibi yapılmasıydı. Kısacası Ahmet İnsel'e göre eylemler tamamen eylemcilerin demokratik hak ve taleplerini dikkate almayan siyasal aktörlere karşı ve sivil itaatsizlik bağlamında bir katılımcı demokrasi talebi olduğu üzerinde durmaktadır. (Radikal, 16 Temmuz 2013). Ahmet İnsel, 'Her Yer Taksim, her yer demokrasi', Radikal, 16 Temmuz 2013). Bu bağlamda hürriyet gazetesi yazarı Ahmet Hakan’a göre gösteriler geçmişte 'ordu göreve' diye pankart açanların, bir avuç kaymak tabakanın, derin güçlerin ön ayak olduğu, yasadışı örgütlerin eylemlerine hiç benzemiyordu. Zira Hakan eylemcileri "sokağa çıkan çocuklar süper bağlantısız, 
süper acemi, süper hercai ve süper naif” bir grubun "süper" üyeleri olarak tanımlarken eylemleri ise yasadışı eylemlerden ayırarak, yine "süper" sıfatı ile nitelendirmektedir (Ahmet Hakan, "Aşkolsun Çocuklar Size Aşk Olsun,” Hürriyet, 6 Haziran 2013).

Eylemlere karşı çıkan ve eylemcileri şiddet yanlısı ve darbeci olarak tanımlayan gruplara göre ise, eylemlerin barışçıl kaldığı birkaç günün sonrasını 'çevre hassasiyeti' veya 'özgürlük mücadelesi' gibi pozitif faktörlerle açıklamanın mümkün olmadığ . $^{3}$ şeklinde değerlendirilerek eleştirilmiştir. Eylemlere bu açıdan yaklaşıldığında, barışçıl şekilde başlayan ancak kısa bir süre sonra marjinal sol örgütlerin ajandalarına esir düşen Gezi Parkı eylemleri, "post-28 Şubat prodüksiyonu”, "bir sivil darbe hevesinin provası"4 ve "dijital darbe girişimi”’ olarak görülmektedir. "Gezi Parkı diye başlayıp yurt çapına yayılarak sandık tanımaz bir Türk ayaklanmasına dönüşen olaylar" "Türkiye’nin demokrasinin işlemediği bir ülke olarak gösterilmesi”’ çabası olarak tanımlanmaktadır. Bu haliyle Gezi eylemleri, barışçıl sivil hareketin değil, bir "sivil toplum darbesi”nin önünü açmanın, ${ }^{8}$ ülkenin huzurunu, istikrarını bozmaya ve güvenini sarsmaya yönelik yurtdışı destekli bir operasyonun ${ }^{9}$ izdüşümü olarak değerlendirilmektedir (Ete, Taştan, 2013-90-95).

3 'Başbakan Bu Tayyip Erdoğan Değişmez', Hürriyet, 12 Haziran 2013, http://www.hurriyet.com.tr/gundem/23479966.asp;http://siyaset.milliyet.com.tr/baska-bir-noktaya-dogru-yol aliyor/siyaset/detay/1719847/default.htm

4 Nihal Bengisu Karaca, 'Samimi Müşteki, Organize Müfteri', Habertürk, 5 Haziran 2013,

http://www.haberturk.com/yazarlar/nihal-bengisu-karaca/850099-samimi-mustekiorganize-mufteri

5 'Gezi Parkı Dijital Darbe Girişimidir', Yeni Şafak, 23 Haziran 2013, ht tp://yenisafak.com.tr/roportaj-haber/gezi-parki-dijital-darbegirisimidir-18.07.2013-534955

6 Nihal Bengisu Karaca, 'Hasar Raporu', Habertürk, 19 Haziran 2013, http://www.haberturk.com/yazarlar/nihal-bengisu-karaca/853424-hasar-raporu

7 Nihal Bengisu Karaca, 'Hasar Raporu', Habertürk, 19 Haziran 2013, http://www.haberturk.com/yazarlar/nihal-bengisu-karaca/853424-hasar-raporu

8 Omar Encarnación, 'Even Good Coups are Bad', Foreign Affairs, 9 Temmuz 2013, http://www.foreignaffairs.com/articles/139570/omar-encarnacion/even-good-coupsare-bad

9 Hilal Kaplan, 'Ağaç ve Hükümet', Yeni Şafak, 2 Haziran 2013, http://yenisafak.com.tr/yazarlar/HilalKaplan/agac-ve-hukumet/37971; 
$\mathrm{Bu}$ değerlendirmeler, eylemlerin arkasındaki itici ve/veya çekici gücün, 2002 yılının Kasım ayında yapılan genel seçimlerden bu yana katıldığ tinin illegal yollarla zayıflatılması ve/veya iktidardan düşürülmesinin hedeflendiği yönünde algı oluşturulmaktadır. Eylemleri olumlamayan birçok siyasal çevrede farklı ağırlık ve tonlarla mevcut olan bu değerlendirmeye göre, seçimlerin AK Parti iktidarını sonlandırmayacağı anlaşılinca sokaklar devreye sokulmuştur. Nitekim bu çerçevede, BDP Genel Başkanı Selahattin Demirtaş, Gezi eylemleriyle oluşan hareketliliğin, darbeye davetiye çıkartmaya çalışıldığını, sivil hareketten bir darbe çıkarma çalışmalarına şahitlik edildiğini beyan etmiştir. ${ }^{10}$

Mısır'da 3 Temmuz darbesine giden sürecin de sokak eylemleri ile başlamış olduğunu hatırlatan Başbakan Erdoğan da "Geçmişte darbeler askerin sokağa çıkması, sıkıyönetim ilan etmesi, televizyon ve radyoları işgal etmesiyle gerçekleşiyordu. Bugünlerde ise Mısır'da gördügümüz gibi meydanlar, medya, sosyal medya illegal gösterilere zemin hazırlıyor ve silahlı güçler onun arkasından gelebiliyor" ${ }^{\prime 11}$ diyerek sosyal medyanın provakatif ve yasadışı gösterileri tetikleyici rolünün de var olabileceğine işaret etmektedir.

Özellikle CHP'li Umut Oran'da 1 Haziran 2013 tarihinizdeki twitter mesajında polisin kimyasal silah kullandığı ifade ederek ve Ak Parti siyasetinin Fazişm ve diktatörlük üzerine kurgulandığını ifade etmesi ve Tunceli Milletvekili Hüseyin Aygün de 30 Mayıs 2013 tarihli twittinde "Gezi Parkı" eylemlerinin asıl hedefinin hükümet ve Ak Parti siyaseti olduğunu, gezi parkı eylemlerinin Taksimi yayalaştırma projesi olmadığını açı bir dille ortaya koyması eylemin asıl amacının tanımlanması açısından önemlidir.

Emrullah İşler, 'Arap Baharı’ndan Gezi Parkı'nı Okumak', Yeni Şafak, 18 Haziran 2013,

http://yenisafak.com.tr/yorum-haber/arap-baharindan-gezi-parkiniokumak-19.06.2013-533684

10 Gezi'de Darbe İsteyenlerle Beraber Yürüyemezdik', Star Gazete, 31 Temmuz 2013, http://haber.stargazete.com/politika/gezide-darbe-isteyenlerle-birlikteyuruyemezdik/haber-777447

11 'En Büyük Meydan Taksim Değil' Ntvmsnbc, 11 Temmuz 2013, http://www.ntvmsnbc. com/id/25454409/ 

yolcudur artik bence, hafta sonunu beklesin herkes, asıl şenlik o zaman!

\section{3) Umut Oran}

@UmutOranCHP

4:20 AM - 1 Haziran 13

Halkına aralıksız 20 saattîr kimyasal silah kullanan siyasetin tek bir adı vardır: FAŞízM Buna izin veren iktidarinda adı : DİKTATÖRLÜK tür

Eylemlere ve eylemcilere sempatiyle yaklaşanlarca 'eylemin spontaneliği' eylemlerin, 'birdenbire' olması ve dünya basının yerkürenin diğer noktalarındaki daha vahim krizlere göstermediği ilgiyi Gezi Parkı eylemlerine göstermesi, eylemlerin ulusal ve uluslararası aktörler destekli"68 planlı, organize bir komplo eseri olduğu algısını da beraberinde getirmiştir.69 Eylemlerin Türkiye’nin Uluslararası Para Fonu (IMF) ile 53 yıllık borç ilişkisini sonlandırdığı Mayıs ayına denk gelmesi, Türkiye'de eylemlerin başlamasından bir süre sonra benzer gösterilerin büyümekte olan ülkelerin başında gelen ve bir süre önce IMF ile borcunu tamamen kapatan Brezilya' da da başlaması ve son olarak eylemlerin sona ermesinden kısa bir süre sonra Mısır'da 3 Temmuz darbesinin meydana gelmesi Gezi Parkı’nın uluslararası boyutunu gündeme getirmiştir.

Eylemler süresince dile getirilen söylem, taşınan pankartlar ve yazılan sloganlar göz önüne alındığında ("Faşizme Karşı Omuz Omuza", "Hükümet İstifa", "Tayyip İstifa", Mustafa Kemal'in Askerleriyiz", Direne Direne Kazanacağız" Bu Daha Başlangıç Mücadeleye Devam” gibi) gezi parkı eylemlerinin ortak hedefinin hiç şüphesiz Başbakan Erdoğan olduğu söylenebilir. Eylemlere destek veren bir yazarın da kabul ettiği 


\section{Toplum}

üzere, "Sayın Başbakan, evet öyle, mesele sizden başkası değil, meselenin en merkezi yerinde siz yatiyorsunuz." 12 ifadesi ve sosyal medyada paylaşılan;

Tweet Bahtiyar MiRoĞLU
ARKADAŞLAR! HÜKÜMETİ
BUGÜN DÜşÜRDÜK,
DÜşÜRDÜK. YOKSA BİR DAHA
KUYRUĞUMUZU DİKEMEYİ.
\#GeziParkıCanlaBaşla
\#direngeziparkı
16:34-31 May 13
$\mathbf{7}$ RETwEet 5 FAvori

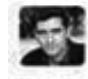

Memet All Alabora

alometalavabora

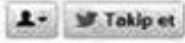

Mesele sadece Gezi Parkı degil arkadaş, sen

hâlâ anlamadın mi? Hadi gel.

vdirengeziparka

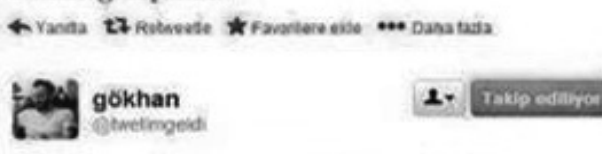

mesele sadece gezi parkı olayı değil.buradan yola çıkıp gerçek gücün halk olduğunu göstermenin tam surası.isyansa isyan! bu hükümet düşecek!

\section{ModernMaço}

Tamodernmace

\section{Tratipedilion}

direngeziparka Cumhuriyet tarihinin en buyuk ayaklanmasinin ilk adimi olsun insallah! $=$ BASARIYORUZ

12 74. Hasan Cemal, 'Türkiye hızla tehlikeli sulara doğru seyrediyor! Ve Sayın Başbakan, mesele sizden başkası değil!, T24, 17 Haziran 2013, 
Kurgu ile Gerçeklik Arasında Gezi Parkı Eylemleri ve Soysal Medya

Ece Temelkuran

1. Raund alındı. Maç yeni başlıyor. Devleti anlayışlı bir amca sanmayın. Bu gece Taksim'i yalnız birakmayn. \#occupyistanbul \#direnistanbul

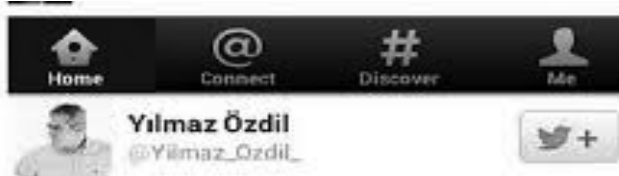

24 saat daha devam edersek $A B$ kararnyla hükümet düşecek. Yayın bunu. Herkes bilsin. Az kaldı direnelim..! \#türkiyemdireniyor \#direngaziparkı

$3: 34 \mathrm{pm}-1$ Jun 13

7,872 RETWEETS 269 FAVDATIES

ve özellikle Türkiye Barolar Birliği Başkanı Metin Feyzioğlu’nun gönderdiği

ONEMLI - TÜRKIYE BAROLAR BIRLiĞi
BASKANINıN isTEĞi VAR!
"Arkadaşlar vakti olanlar acil servislere gidip
yaralı arkadaşların fotoğraflarını
Çeksinler,kendi yaralarını fotoğrafla
belgelesinler ve üşenmeden 2 satır dilekçe
yazıp suc duyurusunda bulunun,nerde nasıl
yaralandığınız ve 1 tanıkta ekleyiniz,baro
birliklerine dilekçeler versinler çok ama çok
önemli Iütfen üşenmeyin, iktidara resmi
yollardan yıpratmanın ve dünyanın devreye
girebilmesi için dilekçeler ve belgeler çok
önemli,toplayabildiğiniz kadar gaz fişeği vs
toplayın."
T.B.B Başkanı Metin FEYZioĞLU


şeklindeki twitt; eylemin ve eylemcilerin gerçek amaçlarını ve hedeflerini açıkça ortaya koyması açısından önemlidir ve örnekleri çoğaltmak da mümkündür. Özellikle sosyal medya üzerinden üretilen ve tüketime sunulan mesajlarda da bu gerçeklik açık bir şekilde ortaya konmakta ve söylemlerin kamuoyuna bilgi malzemesi sağlamak değil, Chomsky ifadesiyle "kamu zihnini kontrol etme"ye çalışmak ve topluma kendi düşünceleri yaymak olduğunu görülmektedir. Düşünüldüğünde yayma kelimesi propaganda faaliyetlerinin birebir kendisi olduğu görülecektir. Çünkü Curran'nın da ifade ettiği gibi bu bakış açısına göre” kitle iletişim araçlarının (toplumsal iletişim kipi) içerikleriyle mesajlarının taşıdığ 1 anlamlar esas olarak içinde üretildikleri örgütün ekonomik ve ideolojik temeliyle belirlenmektedir (Curran; 1997: 139)

\section{Gezi Parkı Eylemleri:}

\section{Algı İle Gerçeklik Arasındaki Sosyal Medya}

Son yıllarda sıkça telaffuz edilmeye başlanan "alg1 yönetimi” kavramı her ne kadar yakın bir zaman diliminde ABD Savunma Bakanlığına bağlı birimler tarafından terminolojiye kazandırılmış olsa da söz konusu kavrama yüklenen içerik incelendiğinde oldukça eski bir yöntem olduğu anlaşılmaktadır. Zira algı yönetiminin özünü "ikna ve inandırma faaliyetleri” oluşturmaktadır. Bu çerçevede tarih boyunca gerek fert bazında gerekse de kurumsal temel de hedef kitleleri etkilemek için algı yönetim metotlarının kullanıldığı görülmektedir (Öksüz 2013)

$\mathrm{Bu}$ çerçevede devletler bölgesel güç olmak, iktidarlar, siyasal uygulamalarının meşruiyetini sağlamak, kurumlar ve fertler ise itibarını yükseltmek, faydalarını maksimize etmek yönünde toplum mühendisliği, psikolojik harekât, imaj yönetimi, halkla ilişkiler gibi uygulamaları servis etmeye başlamışlardır. Dolayısıyla algı yönetimiyle gerçekler, yansıtma, yanıltma, psikolojik operasyonlar gibi unsurlarla grupların tutum, davranış, mantık ve duygularını algı yöneticileri tarafından etkilenmeye ve şekillendirilmeye başlandığı görülmektedir. Walter Lippman'a göre algı ile gerçeklik arasındaki uçurum modern dünya ile daha da genişleyerek, sosyal, siyasal ve ekonomik hayatın içerisinde yaşanan 
karmaşıklık, iletişim araçlarının (özellikle sosyal medya) zihnimizdeki imgeleri değiştirmesi ile hız kazanmaktadır (Ünüvar, 2013). Dolayısıyla algı savaşlarında etkinliğinin artırması ile sosyal medya yeni mecra olarak karşımıza çıkmaktadır. Başka bir deyişle aktörler arasındaki manipülasyona dayalı enformasyon savaşları artık dijital dünya üzerinden kurgulanmaya başlamıştır.

İnsanlığın adeta illüzyon çağında, sesli, görüntülü, yazılı tam bir ileti bombardımanı ile karşı karşıya kaldığı, algıların gerçekleri gölgelediği, kimi zaman peşinden sürüklediği, hatta özünden saptırdığı günümüz dünyasında 'ileti yönetimi'nin özellikle toplumsal hareketlerde her zamankinden daha çok önem kazandığı görülmektedir.

Toplumsal ve siyasal sorunlara karşı demokratik toplumlarda bireylerin katılımını sağlayarak rahatsızlıklarını dile getirmek ve toplumsal değişimleri sağlamak amacıyla yapılan gerekli ve olumlu çabaları ifadelendirilen toplumsal hareketler, sıradan insanların toplumu bazı açılardan değiştirmek için bilinçli, planlı ve sürekli çabaları olarak görülmektedir (Kök, Tekerek (2012: 60). Demokratik toplumlarda toplumsal sorunları dile getirmek, sorunlara dönük talepler ve çözüm önerileri geliştirerek kamusal alanda tartışarak siyasal alana taşımak toplumsal hareketler aracılığıyla gerçekleşmektedir.

İnternet, özellikle bir kişinin birden çok kişiye hitap edebilmesini, bilginin dağıtımı ve paylaşımının tek elden kontrollü bir şekilde, ağ içerisinde bulunan herkese aynı anda ulaştırılabilmesini ve tartışma platformları oluşturularak belli bir konuda herkesin katılımcı bir özellikte aktif şekilde rol almasını sağlamaktadır (Göker, Doğan 2011: 184). Bu özellikler internetin ve özellikle sosyal medyanın eylem ve örgütlenme açısından en ideal alan olarak kullanılmasını kolaylaştırmaktadır. Bu yaklaşım açısı sosyal medyanın interaktif bir iletişim aracı olması, bireylerin sosyalleşme ve sosyal sermayelerine katkısının bulunması, bireylerin daha özgür ve demokratik bir ortamda düşüncelerini rahatlıkla ifade edebilmeleri gibi olumlu özelliklere sahip olması yaşadığımız zamanın başat medya aracı olarak kabul görülmesine neden olmaktadır (Babacan, Haşlak ve Hira, 2011: 167). Ancak sosyal medya, örgütleyicilerin 
aynı düşüncedeki insanları az bir masrafla harekete geçirdiği düşünülse bile, insanların harekete geçmesinde tamamen etkili değildir (Babacan, Haşlak ve Hira, 2011: 167). İnsanlar eğer bir şeylerden rahatsızlık duymuyorsa ve o ortamda aktarılan düşünceleri paylaşmıyorsa sosyal medyanın etkisi kitleselleşmeyecektir. Sosyal medya, ancak aynı şeylerden rahatsızlık duyan ve benzer düşünceleri paylaşan insanları bir araya getirirse ve sayılarının hiç de az olmadığına inandırırsa, o zaman kitlesel bir eyleme yol açabilir. (Odyakmaz Acar, 2012: 202-218)

Son dönemlerde dünyada farklı ülkelerde yaşanan birçok olayda ve meydana gelen krizlerde, halkın bu yaşananlara karşı tepki göstermesinde, kitlelerin ayaklanmasında, eylemlere bilfiil müdahil olmasında sosyal medya (özellikle Facebook-Twitter) üzerinden yürütülen faaliyetler etkili olmaktadır. Türkiye'de de son dönemlerde yaşanan "gezi olayları" internetin ve sosyal medyanın siyasal alanda nasıl bir etki yarattığ ve kitlelerin nasıl harekete geçtiği noktasında önemli bir örnek teşkil etmektedir. Gezi parkı eylemleri olarak medyada karşılık bulan ve uzun bir süre gündemi işgal eden olayların çıkış noktası İstanbul Taksim Meydanı Yayalaştırma Projesi kapsamında Gezi Parkı’ndaki ağaçların kesilmesi üzerine başlayan protesto eylemlerinin (görünen) başlangıcını oluşturmaktadır. Eylemler sosyal medya aracılığıyla tüm ülkeye ve dünyaya yayılmış ve dünya medyasında da önemli bir yer bulmuştur. Ancak bu noktada, "Gezi Parkı" eylemlerini mümkün olduğu derecede siyasetin ve grup asabiyesine yaslanan bakışın ötesinde, mesafeli ve objektif bir şekilde değerlendirmek önem taşımaktadır.

Sosyal bilimlerde olup bitenleri insanoğlunun yanlış ve tutarsız bir şekilde okumasını önleme amacıyla çeşitli yöntem edinme meseleleri uzun insanlık tarihi boyunca tartışılmıştır. Platon'un Mağaradakiler'den başlayarak Bacon'un dikkat çektiği hususlara, Kant'ın akıl yürütme biçimlerine, Hobbes'un, Haldun'un, Comte’un, günümüze doğru ideolojik tartışmaların düşünürlerine kadar teşekkül etmiş repertuarı hatırlamakta fayda vardır. Sadece Platon'un "mağara metaforunu” düşünerek şunu söyleyebiliriz: Her toplumsal politik grup kendi mağarasında bulunur ve duvara yansıyan "şeyleri" onun prizmasından görür (Bostanc1, 2013). 
$\mathrm{Bu}$ açıdan bakıldığında gezi parkı eylemlerine ve eylemcilerine iki farklı bakış açısının geliştirildiği görülmektedir. Eylemleri ve eylemcileri "sivil demokrat ve barışçıl Y-kuşağı eylemleri olarak görenler" ve eylemleri-eylemcileri "sol, otoriter, şiddet yanlısı ve darbeci" olarak görenler. Her iki grupta grup asabiyesi, grup ideolojisi, kişisel popülarite ve rant elde etme kaygısı gibi nedenlerle sosyal medyayı kendi mağarasının yansıması olarak kullandıkları söyleyebiliriz (Ete,Taştan, 2013-90-95).

Bu bağlamda, "Gezi Parkı” olayı üzerinden farklı siyasal görüşlere mensup bireylerin, gezi eylemlerini kendi ideolojik bakış açılarıyla ele almaları, bazı grup ve bireylerin olayı kullanarak kişisel popülarite ve rant elde etmeye çalışması ve sosyal medya üzerinden yoğun paylaşımlarda bulunması, protestoların çıkış amacını gölgeleyerek amacından sapmasına ve olayların hükümet yanlısı ve hükümet karşıtı grupların çatışması haline dönüşmesine, kitlelerin sokaklara dökülmesine, şiddet olaylarının yaşanmasına ve ülkenin bu olaylar sonucunda ciddi sıkıntılar yaşamasına yol açmıştır. İnternet üzerinden yapılan yoğun paylaşımlar ve her iki taraftan farklı grupların olaylara provakatif yaklaşımı, protesto eylemlerinin sivil bir direniş ve halk hareketi olma iddiasını gölgelediği gibi gerginliğin artmasına ve hatta ölümlerin yaşanmasına sebebiyet vermiştir (Ete,Taştan, 2013-90-95).

Aynı şekilde, İnternette dolaşıma giren ve/veya sokulan bazı bilgi ve haberlerin asılsız olması iki tarafında paylaşılan yazılar, fotoğraflar, videolar üzerinden karşıt grubu aşağılayarak karalamaya çalışması eylemin amacından uzaklaşmasına, gölgelenmesine ve farklı boyutlara taşınmasına yol açmakta ve Platon'un "mağara metaforunun" yansıması olarak değerlendirilebilir. Bu durum yeni teknolojilerin avantaj ve dezavantajlarının görülmesi açısından da önemli bir örnek teşkil etmektedir. Yeni teknolojilerin iletişim engelleri olarak ifade edilen zaman, mekan, sınır kavramlarını ortadan kaldıran ve geribildirimi olanaklı kılan kısa sürede bireyin kitlelere ulaşmasını sağlayan avantajlarının yanı sıra bilgi kirliliğine ve manipülasyonlara açık bir mecra olması ve dolayısıyla internetin bu anlamda tehdit edici bir yönünün de olması sosyal medyayı tartışılır hale getirmektedir. 
Gezi parkı eylemleri sırasında meydana gelen olaylar üzerine Twitter'in en aktif kullanılan sosyal ağ olduğu görülmektedir. Somemto’nun hazırladığı analize göre 31 Mayıs - 6 Haziran tarihleri arasında tam 91.377.342 adet Türkçe tweet atıldığı ortaya çıkmaktadır. Gezi Parkı eylemleri boyunca en aktif olan hashtaglerin başında ise \#direngeziparkı gelmiş (31 Mayıs tarihinde 1 milyon, toplamda ise 2 milyondan fazla tweet paylaşılmış) ve bu hashtag'i ise sırasıyla \#direnankara, \#occupygezi takip ettiği görülmüştür.

Taksim Gezi Parkı Eylemleri sırasında 'Direngeziparki ve direnankara' da paylaşılan tweetlerin yaklaşık yüzde 90'1, occupygezi' de paylaşılan tweetlerin ise yaklaşık yüzde 55'i Türkçedir.

- \#direngeziparki etiketiyle paylaşılan mesajlardan 1.599.977 farklı Twitter mesajı detaylı analiz edildiğinde; Bu mesajların 523.126'sı olayların en sert yaşandığı gün olan 2 Haziran'da paylaşıldığı Bu mesajların 386.275'inin fotoğraf, 10.592'sinin video içerik ile gönderildiği Paylaşılan yaklaşı 1.6 milyon mesajın 139.053'ünün İngilizce, 14.465'inin Almanca, 3.476’sının Fransızca, 2.620'sinin İspanyolca ve 318'inin Rusça olduğu tespit edilmiştir. (Babaoğlan, Banko 2013).

- \#occupygezi etiketiyle paylaşılan mesajlardan 465.556 farklı Twitter mesajı detaylı analiz edildiğinde; Bu mesajların 149.649'u olayların en sert yaşandığı gün olan 2 Haziran'da paylaşıldığı Bu mesajların 121.919'unun fotoğraf, 4.117'sinin video içerik ile gönderildiği Paylaşılan yaklaşı 466 bin mesajın 159.712'sinin İngilizce, 16.918'inin Almanca, 8.195’inin Fransızca, 8.547'sinin İspanyolca ve 412'inin Rusça olduğu tespit edilmiştir. (Babaoğlan, Banko; 2013)

- \#direnankara etiketiyle paylaşılan mesajlardan 154.645 farklı Twitter mesajı detaylı analiz edildiğinde; Bu mesajların 110.298'inin olayların en sert yaşandığ gün olan 2 Haziran'da paylaşıldığı Bu mesajların 31.425'inin fotoğraf, 1.051'sinin video içerik ile gönderildiği Paylaşılan yaklaşık 155 bin mesajın 5.769'unun İngilizce, 214'ünün Almanca, 91'inin Fransızca, 199'unun İspanyolca ve 5'inin Rusça olduğu tespit edilmiştir. (Babaoğlan, Banko 2013, 15-30) 
Ancak atılan twitter mesajlarındaki söylemlere bakıldığında ise genellikle darbe, işgal, saldırı, baskın, savaş, direniş, isyan, ayaklanma, düşmanlık, faşizm, diktatörlük, panzer, toma, hükümet düşecek, gibi olumsuzluk ve nefret uyandıran söylemlerin kullanılması gezi parkında ağaçların kesilmesine karşı başlatılan eylemlerin giderek amacından uzaklaştı̆̆ının açık göstergesi olarak kabul edilebilir. Özellikle gezi parkı eylemlerini demokratik hak ve özgürlükler eylemi ve sivil, barış̧̧ı demokrat Y kuşağının sponten (kendiliğinden) gelişen olaylar olarak değerlendirenler vatandaşların eylemlerin 3. gününden sonraki twitleri sosyal medyanın algı oluşturmak amacıyla, kamuoyunun alg1larını nasıl sahte gerçekler üzerine inşa ettiklerinin anlaşılması ve soysal medyayı kendi gerçeklikleri açısından kullandıklarının açıklanması açısından önemlidir.

Gezi Parkı olaylarına sosyal medyanın kullanım pratikleri açısından bakıldığında kullanıcıların örgütlenmesi, yardımlaşması, yaşanan gelişmelerden birbirlerini haberdar etmeleri gibi pek çok konuda ana akım medyanın önüne geçmiştir. Fakat hem Gezi Parkı olaylarını destekleyenler hem de iktidar yanlısı olan bireylerin Facebook grup sayfalarında paylaştıkları fotoğraf, video ya da durum mesajlarında yanlı tutumlar sergilenmesi, gerçekleştirilen eylemi amacından saptırma yoluna soktuğu da söylenebilir.

Özellikle gezi parkı eylemleri sırasında sosyal medya üzerinden yapılan yoğun paylaşımlar grupların olaylara provakatif yaklaşımı, protesto eylemlerinin sivil direniş, hak ve özgürlük talebi, halk hareketi olma özeliğinin gölgelenmesine neden olmuş ve kitlelerin sokaklara dökülmesine şiddet olayların yaşanmasına sebep olmuştur.

Her üç hasteng fotoğraflar yoğun bir şekilde kullanılmış ve bunların büyük bir çoğunluğunun halkı sokağa dökme, provakatif, ve kışkırtma amaçlı kullanıldığı ortaya çıkmıştır. yani sosyal medya üzerinden paylaşılan verilerin, tıpki geleneksel medyada olduğu gibi, hangi yönde etki yaratılmak isteniyorsa o yönde kamuoyunun oluşturulabileceğini ortaya çıkmaktadır. Örneğin gösterilerde Aylin isimli bir eylemcinin 
polis panzeri altında ezilerek öldügü haberlerinin sosyal medyada yayılması neticesinde halkın sokaklara dökülmesi ve şiddet eylemlerinin artması sosyal medyanın provakatif ekti gücünün ortaya konulması açısindan önemlidir.

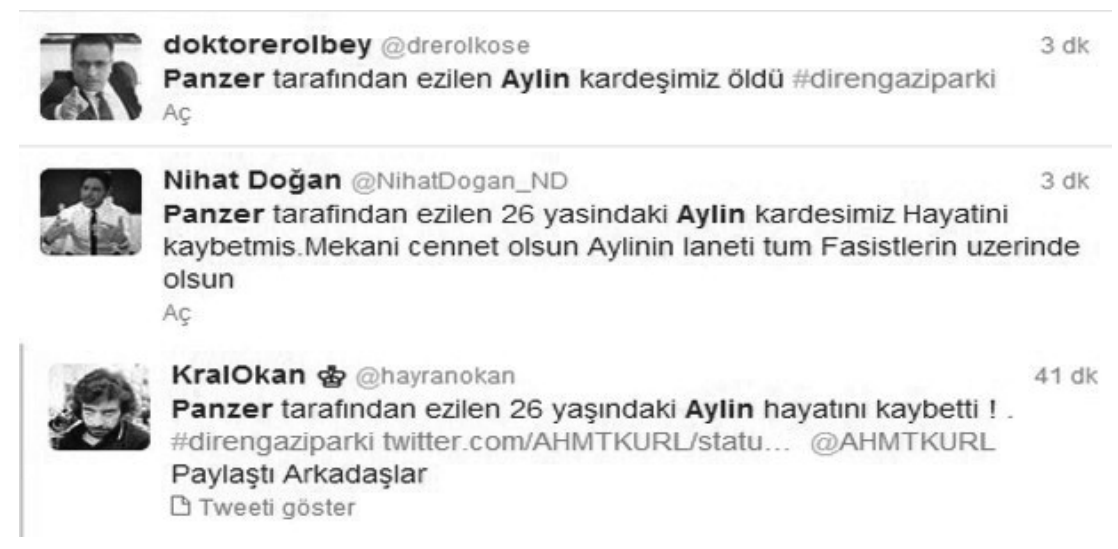

Yayınlanan bu twitler sonucunda CHP genel başkan yardımcısı Adnan Keskin'nin “genç bir kızın eylemler sırasında panzerlerin altında kalarak öldüğünü açıklaması” ve bu yalan haberin, Haber, HalkTV, Ulusal Kanal gibi medya kanallarından anında son dakika haberi olarak geçilmesi (dünya bülteni-güncelleme 01 Haziran 2013) duygusal olarak bir çok kişiyi ayağa kaldırmayı ve eylemlerin şiddetlenmesini başarmıştır. (Panzerle ezilen genç resmi: En çok tepki çeken fotoğraflardan. Olayın aslı yabancı bir ülkede bot motorundan yaralanan bir kişi olduğu ortaya çıkmıştır). ${ }^{13}$

Aynı şekilde polisin eylemler sırasında bırakın insanları sokak hayvanlarına dahi biber gazı sıktığı haberinin fotoğraflar ile hastenglerda paylaşılmasının yine provakatif amaçlısahte bilgi ortaya çıkmıştır. bu fotoğrafın gerçeğinin ise eylemler sırasında değil İtalya' daki bir eyleme ait olduğu ortaya çıkmıştır. 


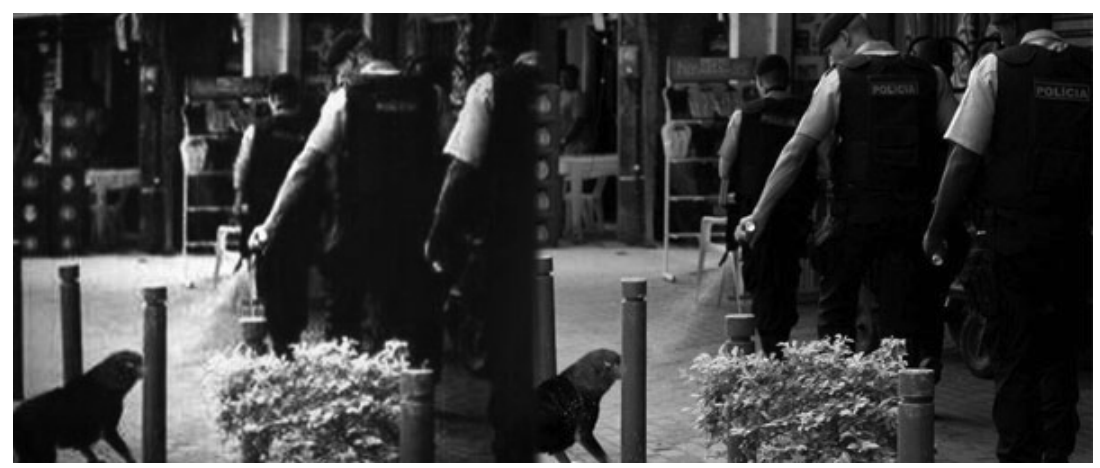

Sosyal medyada yer alan ve doğru olmayan söylentilerden diğeri de, Anayasa Mahkemesi'nin, Türkiye'de böyle bir kanun olmadığı halde gösterilerin 48 saatten fazla sürmesi halinde hükümeti görevden alacağıdır. Amaç eylemcilerin eylemlerine devam etmesini sağlamak olduğu açık bir şekilde kendisini göstermektedir.

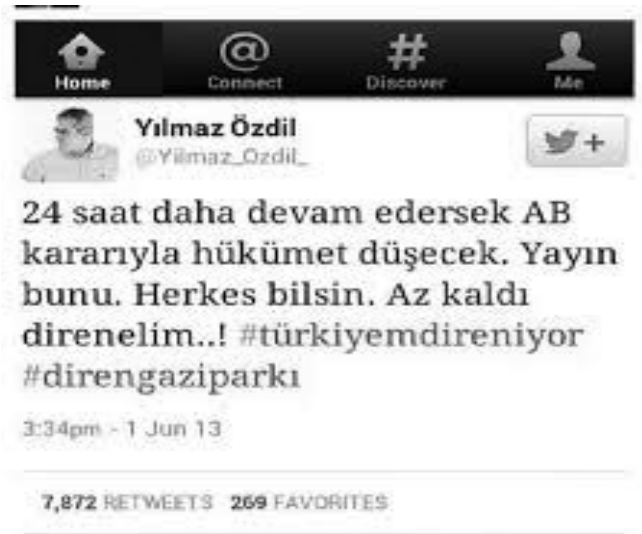

Sosyal medyada paylaşılan ve vatandaşların eyleme destek vermelerini sağlayan bir fotoğrafında yine gerçek dışı olduğu ortaya çıkmıştır. Trafik kazasında yaralanan gencin sanki gezi parkı eylemleri sırasında yaralanmış gibi gösterilmesi, vatandaşların hükümet yönünde eyleme geçmesini sağlamıştır. 


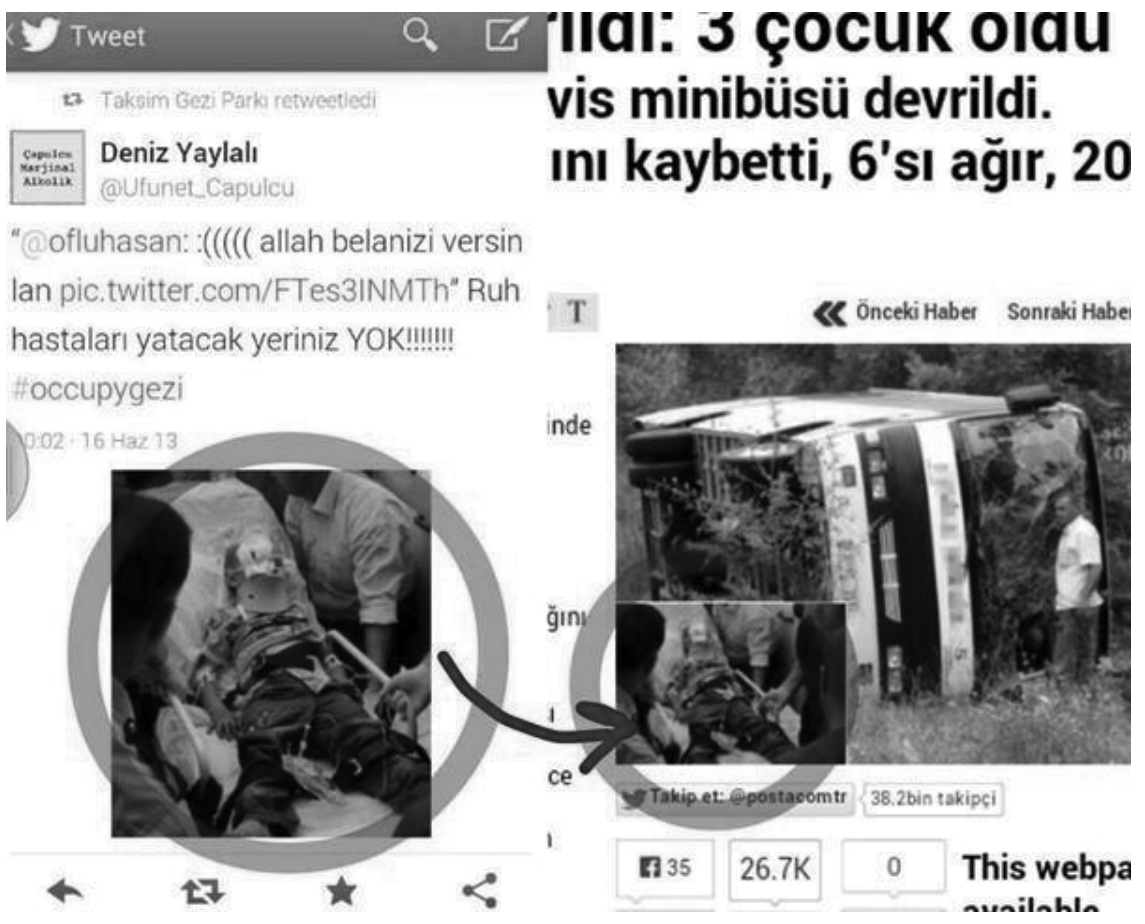

Aynı şekilde eylemcilerin Dolmabahçe Camiinde içtikleri bira kutularının fotoğraflarının yayınlanması da eylemcilere karşı bakış açısını değiştirmiştir. Ancak cami imamı ve müezzinini açıklamalarından sonra paylaşılan bilginin yalan $\mathrm{m}$ gerçek mi olduğunun tartışılmaya açılmasını da beraberinde getirmiştir.

Bütün bu anlatılardan yola çıkarak, (ister provakatif amaçlı olsun ister tamamen nesnel bilgilerin aktarılması amaçlı olsun), Gezi Parkı eylemlerinin başlamasından bu yana bilginin yayılmasında sosyal medya merkez haline geldiği görülmektedir. Özellikle son birkaç yıl içerisinde, sosyal medyanın, devrimleri ve protestoları tanıtma ve organize etmedeki rolü önemli bir konu haline gelmektedir. Kısaca; Wall Street'i İşgal Et eyleminden, Arap Baharı devrimlerine ve gezi parkı eylemlerine kadar sosyal medyanın siyasal katılıma katkısını anlamamıza yeni katmanlar eklemiştir. 
Kurgu ile Gerçeklik Arasında Gezi Parkı Eylemleri ve Soysal Medya

\section{Sonuç}

Günümüzde hakim iletişim araçlarının dolaşıma soktuğu ve gündemde tuttuğu mesajların ve görüntülerin anlamını belirleyen sadece mesajın ve görüntülerin sembolik inşasından daha çok, nasıl bir bağlam içinde tüketime sunulduğudur. Çünkü çoğunlukla üretilen mesajların ve görüntülerin yaşananların doğrudan kanıtı olarak sunulması mesajların ve görüntülerin yayınlandıkları iletişim araçlarının ve üreticilerinin ideolojik-sosyal-kültürel çerçeveleri içerisinde yeniden anlamlandırılmaktadır. Dolayısıyla üretilen mesajlar ve görüntüler belli bir etkiyi canlı tutacak nitelikteki kurgulanmaktadır. Bu yüzden kitle iletişim araçları ve özellikle sosyal medya üzerinden tüketime sunulan mesajların ve görüntülerin hangilerinin kurgulanmış ve manipülatif içerikler taşıdığı, hangilerinin gerçeğin belgesi olduğu önemli hale gelmektedir.

Günümüzde sosyal medya aracıllğıyla Facebook, Twitter, Instagram, Thumbler, Foursquare, Vine ve benzeri uygulamalar üzerinden iletişim kuran bireyler duygu, düşünce ve toplumsal alanda yaşanan olaylara karşı sergiledikleri tutumlarını görsel-işitsel-yazılı paylaşmakta, (-ki bunlar fotoğraf, video, yazılı mesaj-) bu paylaşımlar zaman zaman kitleleri yönlendirecek şekillerde kamusal alanda karşılığını bulmaktadır. İnternet aracılığıyla siyasal içerikli paylaşımların yapılması, geniş kitlelerin bu olaylara dahil olmasını sağlamakta dolayısıyla kitlelerin yaşanan olaylara direk dahil olması sonucunu beraberinde getirmektedir

Özelilkle 2004 yılından itibaren sosyal medyanın, bireylerin organize olmasını kolaylaştırma, olaylar hakkındaki bilgilerin kolaylıkla öğrenilebilme, bireyler arasındaki etkileşimi artırma, fikirlerin kolay ve hızlı bir şekilde yayma, iletişim maliyetlerini düşürme ve bireylerin hem üreten hem de tüketen konumuna getirme gibi imkanlar sosyal medyayı toplumsal hareketlerde geleneksel medyaya göre bir adım daha öne çıkarmaktadır. Sosyal medyanın sağladı̆̆ı bu imkanlar günümüzde elinde bir kamere ile görüntüler çeken, olayları kurgulayarak kendi bakış açılarını ortaya koyan insanların tüketime sundukları bilgiler sonucunda sosyal topluluklar kurabilmekte örgütlenebilmekte ve harekete geçebilmektedir. 
Aynı şekilde, son dönemlerde dünyada farklı ülkelerde yaşanan birçok olayda ve meydana gelen krizlerde, halkın bu yaşananlara karşı tepki göstermesinde, ayaklanmasında ve eylemlere bilfiil müdahil olmasında sosyal medya (özellikle Facebook-Twitter) üzerinden yürütülen faaliyetler etkili olmaktadır. Türkiye'de de son dönemlerde yaşanan "gezi olayları" sosyal medyanın siyasal alanda nasıl bir etki yarattı̆̆ 1 ve kitlelerin nasıl harekete geçtiği noktasında önemli bir örnek teşkil etmektedir. Gezi parkı eylemleri olarak medyada karşılık bulan ve uzun bir süre gündemi işgal eden olayların çıkış noktası İstanbul Taksim Meydanı Yayalaştırma Projesi kapsamında Gezi Parkı́ndaki ağaçların kesilmesi üzerine başlayan protesto eylemlerinin (görünen) başlangıcını oluşturmaktadır. Eylemler sosyal medya aracılığıyla tüm ülkeye ve dünyaya yayılmış ve dünya medyasında da önemli bir yer bulmuştur.

Sosyal medyanın insanları etkileme gücü göz önünde bulundurularak kurgu ile gerçeklik arasında Gezi Parkı eylemleri ile ilgili sosyal medyada yer alan mesajların (gazeteciler-sanatçılar, siyasetçiler) farklı söylemlerin inşa edilişine tanıklık etmiştir. Gezi Parkı eylemlerine bir sivil demokrasi hamlesi olarak sahip çıkan ve/veya hareketin Başbakan Erdoğan başta olmak üzere Ak Parti hükümeti, hükümet politikaları ile bu siyasi aktörlerin temsil ettiği değerler bütününe karşı eleştirel yaklaş1mını kendisine yakın bulan yorumcular, eylemlere katılan eylemcilere dair bazı olumlu varsayımlar ürettiği görülmüştür. Bu muhayyel ortalama eylemci profili, kamuoyunda yaşanan tartışmalarda sorgulanmaksızın dolaşıma sokulmuş ve toplumun belirli bir kesiminin gösterilere dair algısını büyük ölçüde şekillendirilmiştir.

Bu bağlamda, Gezi parkı eylemleri sırasında gerek gazetecilerin, sanatçıların ve gerekse siyasetçilerin büyük çoğunluğunun demokratik, objektif ve nesnel bilgi üretilmesinden ve paylaşılmasından daha çok eylemleri "mağara metaforu"ndan gördükleri ve söylemleri ile kamuoyunu etkilemeye çalıştıkları görülmüştür. Çünkü gezi parkı eylemlerini "kelle isteyen yeniçeriler, sarhoş kafayla eylem yapanlar, dijital darbe girişimi, iç ve dış güçlerle bağlantısı olan aşırı uçların organizasyonu olarak görüp değerlendirilenler olduğu gibi, eylemleri “Türk baharı, özgürlük talebi, 
haykırışın sembolleşmesi, demokratik halk eylemi” olarak görenlerde bulunmaktadır. Ancak bu noktada önemli olan, "Gezi Parkı" özelinde toplumsal hareketler genelinde, eylemlere mümkün olduğunca siyasetin ve grup asabiyesine dişında, mesafeli ve objektif bir şekilde değerlendirmek önem taşımaktadır. 


\section{Kaynakça}

Akıncı Vural, Berril Z; Bat Mikail (2010). Yeni Bir İletişim Ortamı Olarak Sosyal Medya: Ege Üniversitesi İletişim Fakültesine Yönelik Bir Araştırma, Journal of Yasar University. Ankara.

Babacan Mehmet Emin, Haşlak İrfan, Hıra İsmail, (2011). Sosyal Medya ve Arap Baharl, http://www.aid.sakarya.edu.tr/uploads/Pdf_2011_3. pdf (Ağustos 10, 2011 tarihinde erişilmiştir).

Babaoğlan Ali Rıza, Banko, Melten (2013) Gezi Parkı Sürecine Dijital Vatandaşin Etkisi, Haziran 3013.

Balcı Şükrü, Tarhan Ahmet ve BAL Enes (2013), Medya ve Siyasal Katılım, Literatürk Academia, Konya.

Balıbar, Etienne (1991) Althuser İçin Yazılar (Çev Hülya Tufan) İletişim Yayınları, İstanbul.

Baudrillard, Jean, (2005) Simülaklar ve Simülasyon (Çev. Oğuz Adanır) Doğu- Batı Yayınları

Binark, Mutlu (2007). Yeni Medya Çalı̧̧maları, Dipnot Yayınları, Ankara.

Bostanc1, Naci (2013) Gezi Parkı Eylemlerini Anlamak "http://www.zaman.com.tr/yorum_gezi-parki-olaylarini-anlamak_2098795.html

Astells Manuel (2005). A ̈̆ Toplumunun Yükselişi Enformasyon Çağg: Ekonomi, Toplum ve Kültür, Ebru Kılıç (Çev.), İstanbul Bilgi Üniversitesi Yayınları, İstanbul.

Curan, James (1997). Medya ve Demokrasi Yeniden Değer Biçme (Çev. Süleyman İrvan), Ark Yayınları, Ankara.

Çildan Cihan, ERTEMİZ Mustafa vd (2012) Sosyal Medyanın Politik Katılım Ve Hareketlerdeki Rolü, XIV. Akademik Bilişim Konferansı, Uşak Üniversitesi 1-3 Şubat 2012 Uşak. 
Dilmen, Necmi Emel (2007), Yeni Medya Kavramı Çerçevesinde İnternet Günlükleri-Bloglar ve Gazeteciliğe Yansımaları, Marmara İletişim Dergisi, Sayı:12.

Ersöz, Selva (2005). İnternet Ve Demokrasinin Geleceği, Selçuk Üniversitesi İletişim Fakültesi Dergisi, Cilt 3, Sayı 4, Konya.

Ete Hatem, Taştan Coşkun (2013) "Kurgu İle Gerçeklik Arasında Gezi Eylemleri”, Siyaset, Ekonomi ve Toplum Araștırmaları Vakfı (SETA) Araştırması, Ankara.

Göker, Göker, Doğan Adem (2011) Ağ Toplumunda Örgütlenme: Facebook'ta Çevrimiçi Tekel Eylemi, Balıkesir Üniversitesi Sosyal Bilimler Enstitüsü Dergisi, 14 (25).

Kaplan, Kenan; Ertürk Elif (2012). Dijital Çağ ve Bireyin İdeolojik Aygitları, The Turkish Online Journal Of Design, Art And Communication - Tojdac October 2012 Volume 2 Issue 4.

Kök Selcen; Tekerek, Mehmet (2012). Sokak Siyasetinden Sosyal Ağlara Yeni Aktivizm: Arap Baharı Deneyimi, II. Bölgesel Sorunlar Ve Türkiye Sempozyumu, Kahramanmaraş.

Lyotard, Jean François (2000). Postmodern Durum (Çev Ahmet Çigdem). Vadi Yayınları, Ankara.

Nalçaoğlu, Halil, (2011), “ Yeni Toplumsal İletişim Ethos’u İstanbul Gençliği Ve İletişim Teknolojilerini Kullanımı, Katılımın E-Hali Gençlerin Sanal Alemi” (Ed. Aslı Telli Aydemir) Alternatif Bilişim, İstanbul, 163-165

Odyakmaz Acar, Necla (2013) Özgürlük Alanı Olarak Sunulan Sosyal Medya ve Taksim Gezi Parkı Eylemleri, Akdeniz İletişim Dergisi S. 20.

O'reilly, Tim (2007). What is Web 2.0: Design Patterns and Business Models fort the Next Generation of Software?, Communication and Strategies, 65 (1)

Öksüz, Harun (2013). Alg1 Yönetimi ve Soysal Medya İdarecinin Sesi, 2013, /156.Sayı/3 erişim 15-04-2014 www.tid.web.tr/ortak_icerik/tid.web

Postman, Neil, (2009). "What is Media Ecology?", Retrieved February, 5, from http://www.media-ecology.org/media_ecology/index.html.) 
Timisi, Nilüfer (2003). Yeni İletişim Teknolojileri ve Demokrasi. Dost Yayınevi, Ankara.

Topbaş Hasan, Babacan Mehmet Emin (2013). Siyasal İletişim Sürecinin Yapısal Dönüşümü ve Siyasete Yansıma Biçimi: Dijital Devrim, (Ed. Gökhan Tuncel), Küreselleşme ve Uluslar Arası Sistem ve Siyasi Partiler, Bilsam Yayınları, Malatya.

Ünüvar, Nejdet (2013). Dijital Siyaset, Pozitif Yayıncılık, İstanbul

Yeniçıktı, Nagihan Tufan (2014). İletişimsel Eylem ve Facebook: Gezi Parkı Olaylarında Sosyal Medyanın Gücü, Selçuk Üniversitesi İletişim Fakültesi Dergisi, 8 (2).

\section{Gazeteler}

Cemal, Hasan, 'Türkiye Hızla Tehlikeli Sulara Doğru Seyrediyor! Ve Sayın Başbakan, Mesele Sizden Başkası Değil, 17 Haziran 2013,

Dündar, Can, “Taksim: Özlediğimiz Türkiye’nin Maketi,” Milliyet, 8 Haziran 2013,

http://gundem.milliyet.com.tr/taksim-ozledigimiz-turkiyenin/gündemi/ ydetay/1720160/default.htm.

Encarnación Omar, 'Even Good Coups are Bad', Foreign Affairs, 9 Temmuz 2013,

http://www.foreignaffairs.com/articles/139570/omar-encarnacion/evengood-coups-are-bad

Hakan, Ahmet, “Aşkolsun Çocuklar Size Aşk Olsun,” Hürriyet, 6 Haziran 2013,

http://www.hurriyet.com.tr/yazarlar/23443787.asp.

Karaca Nihal Bengisu, 'Samimi Müşteki, Organize Müfteri', Habertürk, 5 Haziran 2013,

http://www.haberturk.com/yazarlar/nihal-bengisu-karaca/850099-samimi-musteki-organize-mufteri

Karaca Nihal Bengisu, 'Hasar Raporu', Habertürk, 19 Haziran 2013, 
http://www.haberturk.com/yazarlar/nihal-bengisu-karaca/853424-hasar-raporu

Kaplan, Hilal, 'Ağaç ve Hükümet', Yeni Şafak, 2 Haziran 2013, http://yenisafak.com.tr/yazarlar/HilalKaplan/agac-ve-hukumet/37971;

İnsel, Ahmet, 'Her Yer Taksim, her yer demokrasi', Radikal, 16 Temmuz 2013,

http://www.radikal.com.tr/radikal2/her_yer_taksim_her_yer_demokrasi-1141911.

İşler, Emrullah, 'Arap Baharı'ndan Gezi Parkı'nı Okumak', Yeni Şafak, 18 Haziran 2013,

http://yenisafak.com.tr/yorum-haber/arap-baharindan-gezi-parkini-okumak-19.06.2013-533684

Özkök, Ertuğrul, “Kimdir Bu İnsanlar?” Hürriyet, 3 Haziran 2013, http:// www.hurriyet.com.tr/yazarlar/23421802.asp

'Başbakan Bu Tayyip Erdoğan Değişmez', Hürriyet, 12 Haziran 2013, http://www.hurriyet.com.tr/gundem/23479966.asp;

http://siyaset.milliyet.com.tr/-baska-bir-noktaya-dogru-yol aliyor/siyaset/detay/1719847/default.htm

'Gezi'de Darbe İsteyenlerle Beraber Yürüyemezdik', Star Gazete, 31 Temmuz 2013,

http://haber.stargazete.com/politika/gezide-darbe-isteyenlerle-birlikte-yuruyemezdik/haber-777447

'En Büyük Meydan Taksim Değil' Ntvmsnbc, 11 Temmuz 2013, http:// www.ntvmsnbc.com/id/25454409/

Gezi Parkı Dijital Darbe Girişimidir', Yeni Şafak, 23 Haziran 2013, http://yenisafak.com.tr/roportaj-haber/gezi-parki-dijital-darbe-girisimidir-18.07.2013-534955 
Abstract: -Gezi Park Events and Social Media between Fiction and ActionThere is no doubt that Gezi Park Events have triggered different political imaginations and directed social scientists to new research agenda. Thus, it is one of the most important facts in Turkish history. This fact is especially important for communication scientists as these events became a social activity and questioned the effect of these events on social media and how these events stimulated the masses. After breaking up by the pedestrian Project of Taksim Square, it is called among media as Gezi Park and as an anti-governmental social activity it spread through Turkey and the world by the effect of social media. "Gezi Park" actions lost their aims because of the fact that individuals from different political views tried to get advantage of the events in their interests and thus they tried to use the media and to turn the result of the events in their favour. Gezi actions especially raised a dispute between pro-government people and against ones and it caused street actions against ruling government and it also caused social and economic crisis. Intensive shares on internet and provocative behaviour of both sides shadowed the claim that the event was a civil resistance movement backed by people. Above all the events increased the tension and besides some killings occurred.

Key words: Politics, social, communication, social media. 